\title{
Gratitude, or the Positive Side of the Relationship with Patients. Development and First Validation of New Instruments: A Scale of Gratitude Perceived by Operators and a Scale of Support Offered by the Gratitude Expressed by Their Patients
}

\author{
Mara Martini, Daniela Converso \\ Department of Psychology, University of Turin, Turin, Italy \\ Email: mara.martini@unito.it, daniela.converso@unito.it
}

Received 28 February 2014; revised 25 March 2014; accepted 21 April 2014

Copyright (C) 2014 by authors and Scientific Research Publishing Inc.

This work is licensed under the Creative Commons Attribution International License (CC BY).

http://creativecommons.org/licenses/by/4.0/

(c) (i) Open Access

\section{Abstract}

The relationship with patients/users is a crucial dimension for helping professionals. It is nevertheless mostly analyzed in its negative connotation, that's to say as a possible cause, for example, of the burnout syndrome, while very few are research works that take into account the positive side of the relationship, as a resource more than a problem, and even fewer are the instruments to measure it. The aim of the present work is the development and the analysis of the characteristics of a scale to measure the gratitude expressed by patients perceived by operators and of a scale to measure the perception of support that gratitude by patients/customers offers to relieve the fatigue of daily commitment and return significance to their work. The two scales were developed and then integrated into a questionnaire including items regarding the negative side of the relationship (exceeding requests from patients) and the Customer-initiated support scale (Zimmermann et al., 2011). The questionnaire was filled in by 267 nurses in Piedmont, Italy. Descriptive analyses on each item, exploratory factor analysis, Cronbach's alpha, analysis of variance, and bivariate correlations were conducted. Both scales show a one-factor solution. The independent sample t-tests highlighted differences between men and women and between people who have families to care for and people who do not. Bivariate correlations signalled a positive relationship between both the gratitude scales and the Customer-initiated support; no relationships are evident with the scale of exceeding request from patients. A limitation of the work is the dimension of the sample: a more extensive administration of the questionnaire is currently in progress that will also permit to more deeply investigate the factorial structure of the scales. The scales will allow 
filling a gap in measuring a central work issue for helping professions.

\title{
Keywords
}

\author{
Gratitude, Relationship with Patients, JD-R Model, Scale Development
}

\section{Introduction}

The significance of the relationship with their patients is often mentioned by health professionals among the reasons for having chosen their job (Grandey, Fisk, \& Steiner, 2005; Homburg \& Stock, 2004; Wright \& Pandey, 2008).

Even if largely criticized for its rhetoric allusion to the relationship with patients, the expression "helping profession" itself stringently originates from the centrality that the relational aspects of the socio-sanitary and educational professions encompass. However, peculiarly or paradoxically, the positive impact and the value as support of such relationship is hardly ever cited in the literature, while countless works have focused on its negative sides.

Specifically, several studies (Cox, Kuk, \& Leiter, 1993, among others) take into account the outcomes of an over-demanding and hence negative relationship with patients (stress, burnout, intention to leave; Lee \& Ashforth, 1996; Jourdain \& Chênevert, 2010). As Maslach (1982) has highlighted since her early studies, burnout is the result of an imbalance between giving and receiving, that's to say, an unequal relationship between the people who offer help, support, caring, without adequate back reward, and the users of the services offered, who are often-and paradoxically—increasing their requests. This is what emerges from Dorman and Zapf's (2004) work, focused on exceeding requests from the users of several services.

In contrast with such unidirectional trend, we underline that the relationship with patients, students, clients, can be regarded at not only as a "request" but also as a "resource".

Requests are all the characteristics of the job and of the organizational context (such as, for example, high workload or fast paces) that require physical or psychological efforts, sometimes well beyond the worker's capacity. On the other hand, resources are all the aspects of the job and of the organizational context (a such as, for example, social support from colleagues and autonomy) that support workers in performing their job and in their professional growth. As Hobfoll (1989) states in his Conservation of Resources (COR) theory, psychological resources, in particular, are built throughout positive experiences (Zimmermann, Dormann, \& Dollard, 2011).

The theoretical framework of this study, the Job Demand-Resources (JD-R) model (Bakker, Demerouti, \& Schaufeli, 2003), describes the complex interactions between the resources available for workers and the requests from their job. The authors specifically outline a "dual process" that is induced by both requests and resources. The first process, due to exceeding requests, is a progressive exhaustion of workers health and the consequent reduction in productivity and increase of absenteeism. The second one-the consequence of availability of resources for the worker-is an improvement in the ability to cope with diverse demands and to achieve professional goals as well as an increase in involvement at work.

Even if the JD-R model has previously been used to analyse experiences at work of health professionalsalso in Italian studies (Lo Presti, 2013), the second, positive side of the model, has rarely considered the relationship with the patients (Martini \& Converso, 2012) among resources and its possible protective function (Converso, Gattino, \& Loera, 2009). Among the few research works on this topic we can mention Zimmermann and colleagues' (2011), focused on the support from the customers' positive behaviour in a service.

According to the approach of Positive Psychology (Mills \& Fleck, 2013), investigating aspects that are resources for workers and thus contribute to the increase in personal and professional workers' well-being, is therefore valuable. It can have positive consequences, such as increased productivity, performance improvement, reduction of the risk of clinical errors, and better service quality and users' satisfaction (Ferrara, Converso, \& Viotti, 2013).

Recently, gratitude has become a subject of interest for several Positive Psychology scholars (among others, Emmons, 2007). Gratitude is usually considered, also according to common sense, as a psychological positive characteristic related to a feeling of well-being (Toussaint \& Friedman, 2008) and it is seen as a strength typical 
of some individuals (Peterson \& Seligman, 2004). It has been regarded at and analysed as a trait, a mood, a moral virtue, an emotion. In his "The Stress of life" (1956), Selye underlined that the emotion that can highly reduce or foster stress in human relationships is precisely the feeling of gratitude. People who adopt behaviors that elicit gratitude, also receive approval thus increasing their wellbeing and self-esteem. Gratitude is, in other words, an "emphatic emotion" (Lazarus \& Lazarus, 1994), that can be defined as a response to behaviors that other people perform to contribute to the wellbeing of someone and that may in turn activate analogous behaviors (McCullough, Kilpatrick, Emmons, \& Larson, 2001; McCullough, Emmons, \& Tsang, 2002).

No study, however, has ever addressed gratitude expressed to professionals of the services by their users or patients, i.e. gratitude received by professionals, in other words, the positive counterpart of exceedingly demanding behaviors by patients and users, the so-called Customer-related social stressors described by Dormann and Zapf (2004).

During the qualitative phase (interviews and focus groups) of the research that preceded the development of the scales presented in this work, several health professionals have testified gratitude as above described. Moreover, several health operators, when asked to describe what aspects assist them in performing their work, reported expressions of gratitude by their patients and stated that they feel rewarded and supported by such expressions.

In this way, gratitude expressed by patients is a form of social support that, as Zimmermann and colleagues (2011) remind, may be defined as a resource to buffer stress. Specifically, for the health operators we interviewed, gratitude expressed by patients is a resource because it relieves the fatigue of daily commitment and returns significance to their work.

The activity of professionals working in helping professions does not, in fact, produce any "tangible" result, that might itself be a source of satisfaction, but it is characterized by the repetition of the same gestures over and over (it is sometimes defined a "reproductive" job; Balbo, 1982), often without any manifest outcome. For health operators, not seeing the result of their work can lead to progressive disinvestment in their job, or, sometimes, even to the decision to leave (Hasselhorn et al., 2008). Therefore, the gratitude expressed by patients may be both a reward for the efforts in working and a confirmation of the expected result (i.e. the wellbeing of the patients who have expressed their gratitude).

\section{Aim}

Since the literature lacks in references and instruments focused on these aspects of the relationship with patientsaspects that can no longer be overlooked taking into account the ever-growing amount of requests and resources for health professionals - the present work is aimed at developing and starting to validate two new scales: the first one (Gratitude perceived by operators) measuring the gratitude perceived by operators as the positive side of the relationship with patients/customers; the other one (Perception of support offered by patients/customers' gratitude) measuring the perception of support that gratitude expressed by patients/customers offers to relieve the fatigue of daily commitment and to return significance to professionals' work.

\section{Method}

\subsection{Procedure and Instruments}

In order to develop these instruments, 12 interviews and 2 focus-groups with 24 health operators-who are usually in relationship with patients or customers during their working hours-were conducted. The transcripts of the subjects were analyzed to identify the contents and the issues of their relationships with patients/customers, particularly focusing on the positive aspects of the relationship. As a result, we identified the theme of the perception of gratitude expressed by patients/customers towards operators and the theme of gratitude as a source of "relief" for the effort at work and of significance for their work and their commitment. Some sayings expressed by the operators interviewed were used to develop the items of patients/users' gratitude. We generated a first version of the two scales, respectively composed of 6 and 8 items, with the intent to highlight the several facets of gratitude expressed by patients or users. We chose to develop quite brief scales that can more easily be inserted into instruments to investigate several constructs. For both scales we decided to use a five-point scale ranging from $1=\mathrm{I}$ completely disagree to $5=\mathrm{I}$ completely agree, in line with Zimmermann and colleagues (2011). 
We administered the scales to 40 nurses for a comprehension pre-test. Their feedback induced us to eliminate 1 item from each scale because they seemed controversial (Rattray \& Jones, 2005).

The scale of Gratitude perceived by operators is now composed of 5 items and the scale of Perception of support offered by patients/customers' gratitude is composed of 7 items. They were inserted in a questionnaire that included a personal data section and the following two scales:

- The Dorman \& Zapf's (2004) Customer-related social stressors (Italian adaptation; Taddei \& Vanni, 2008): Likert scale ranging from $1=$ Not true at all to $5=$ Completely true (e.g.: "Our patients are unable to wait").

- The Zimmermann and colleagues' (2011) Customers-initiated support: Likert scale ranging from 1 = I completely disagree to 5 = I completely agree (e.g.: “The customer trusted in my competencies”).

\subsection{Participants}

The questionnaire was completed by 267 nurses and health operators in three hospitals in a North-Western region of Italy. The participants were $85.9 \%$ women, $14.1 \%$ men; $50.6 \%$ had children and $20.8 \%$ had other family members to care for. The average age was slightly higher than 42 years (SD 8.10) and the average job tenure in the health sector was about 17 years (SD 9.04). Their average working time was of 45.5 hours per week (SD 13.4).

\subsection{Data Analysis}

Data were analyzed by means of the statistical package SPSS 20. After descriptive analysis (M, SD; Asymmetry, Kurtosis; Normality tests) of single items of the two scales, explorative factor analysis was conducted in order to start to study the psychometric characteristics of the scales. Moreover, we checked the reliability of each factor by Cronbach's alpha.

T-test for independent samples was later carried out to test the ability of the two scales to discriminate between groups of subjects: grouping variables were socio-demographic characteristics (such as: being women, having children and having other people to care for) that might be sources of request or resources for health operators (Converso et al., 2009; Colombo, Zito, \& Ghislieri, 2012).

In order to start to verify the validity of the two scales (Campbell \& Fiske, 1959; Hinkin, 1998) we also calculated correlations between them and other constructs. In particular, to test divergent validity, we checked if correlation with Customer-related social stressors (Dorman \& Zapf, 2004), was low or zero. Testing convergent validity was more difficult, because of the lack, to our knowledge, of an Italian validated scale to measure the positive side of the relationship with patients/costumers or similar issues. Therefore, we decided to calculate correlations between the two new scales and the Customers-initiated support scale (Zimmermann et al., 2011), even if not yet validated in Italian.

We then calculated correlations between the two scales and age, job tenure and with hours worked for week that are most common requests from workers (Colombo et al., 2012).

\section{Results}

\subsection{Descriptive Analysis}

\subsubsection{Gratitude Perceived by Operators Scale}

Descriptive analyses (see Table 1) show that the items of the scale of Gratitude perceived by operators do not have a strictly normal distribution. All items are lightly negatively asymmetric. Besides, item 1a has a positive kurtosis value; all the others have negative values. The values of both skewness and kurtosis, however, range between -1.00 and 1.00 , which are the threshold values to assume normality of the distribution (Muthén \& Kaplan, 1985). In spite of this, the normality tests both of Kolmogorov-Smirnov and of Shapiro-Wilk (more powerful; Razali \& Wah, 2011) induce, for all items, to reject the hypothesis of normality of the distributions.

\subsubsection{Perception of Support Offered By Patients/Customers' Gratitude Scale}

Similarly to the items of the Gratitude perceived by operators scale, descriptive analysis for the Perception of support offered by patients/customers' gratitude scale (see Table 2) shows that items do not have a strictly normal distribution. Item $4 \mathrm{~b}$ shows a slightly positive asymmetry while all the others are lightly negatively asymmetric. Also in this case the values both of skewness and kurtosis range between -1.00 and 1.00 , but the two 
Table 1. Descriptive analysis of single items of the gratitude perceived by operators scale.

\begin{tabular}{|c|c|c|c|c|c|c|c|c|c|}
\hline $\begin{array}{l}\text { Gratitude perceived by } \\
\text { operators scale }\end{array}$ & Italian Items & $M$ & DS & Skewness & Kurtosis & $K S$ & $p$ & $S W$ & $p$ \\
\hline $\begin{array}{l}\text { 1a. Several patients } \\
\text { express gratitude for } \\
\text { the care we offer them }\end{array}$ & $\begin{array}{l}\text { 1a. Diversi pazienti } \\
\text { esprimono gratitudine per } \\
\text { la cura che offriamo loro }\end{array}$ & 3.57 & .86 & -.30 & .13 & .24 & .000 & .88 & .000 \\
\hline $\begin{array}{l}\text { 2a. Several patients } \\
\text { appreciate our work }\end{array}$ & $\begin{array}{l}\text { 2a. Diversi pazienti } \\
\text { apprezzano il nostro lavoro }\end{array}$ & 3.60 & .82 & -.07 & -.30 & .23 & .000 & .87 & .000 \\
\hline $\begin{array}{l}\text { 3a. Our patients often } \\
\text { thank us for the care } \\
\text { we offer them }\end{array}$ & $\begin{array}{l}\text { 3a. I nostri pazienti } \\
\text { ringraziano spesso per } \\
\text { la cura che ricevono }\end{array}$ & 3.53 & .86 & -.16 & -.11 & .22 & .000 & .88 & .000 \\
\hline $\begin{array}{l}\text { 4a. Sometimes former } \\
\text { patients come back } \\
\text { simply for greetings } \\
\text { or Christmas wishes }\end{array}$ & $\begin{array}{l}\text { 4a. A volte i pazienti } \\
\text { seguiti in passato tornano } \\
\text { solo per fare un saluto } \\
\text { o gli auguri di Natale }\end{array}$ & 3.33 & 1.10 & -.44 & -.45 & .23 & .000 & .90 & .000 \\
\hline $\begin{array}{l}\text { 5a. The patients can } \\
\text { thank in many ways } \\
\text { for the care they receive }\end{array}$ & $\begin{array}{l}\text { 5a. I pazienti sanno dire } \\
\text { grazie in molti modi per } \\
\text { la cura che ricevono }\end{array}$ & 3.47 & .88 & -.25 & -.12 & .23 & .000 & .89 & .000 \\
\hline
\end{tabular}

Table 2. Descriptive analysis of single items of the perception of support offered by patients/customers’ gratitude scale.

\begin{tabular}{|c|c|c|c|c|c|c|c|c|c|}
\hline $\begin{array}{l}\text { Perception of support } \\
\text { offered by } \\
\text { patients/customers' } \\
\text { gratitude scale }\end{array}$ & Italian Items & $M$ & $D S$ & Skewnes & Kurtosis & $K S$ & $p$ & SW & $p$ \\
\hline $\begin{array}{l}\text { 1b. When one is thanked } \\
\text { by your patients working } \\
\text { seems less heavy }\end{array}$ & $\begin{array}{c}\text { 1b. Quando si riceve } \\
\text { un ringraziamento dai } \\
\text { pazienti il lavoro sembra } \\
\text { meno faticoso }\end{array}$ & 3.57 & .93 & -.38 & -.11 & .24 & .000 & .89 & .000 \\
\hline $\begin{array}{l}\text { 2b. A “Thank you” from } \\
\text { a patient allows you to } \\
\text { face your workload with } \\
\text { much more enthusiasm }\end{array}$ & $\begin{array}{c}\text { 2b. Un grazie dai } \\
\text { pazienti consente di } \\
\text { affrontare il lavoro con } \\
\text { molto più entusiasmo }\end{array}$ & 3.59 & .90 & -.11 & -.59 & .22 & .000 & .88 & .000 \\
\hline $\begin{array}{c}\text { 3b. Some patients' } \\
\text { gratitude repays for the } \\
\text { efforts at work }\end{array}$ & $\begin{array}{l}\text { 3b. La gratitudine di } \\
\text { alcuni pazienti ripaga } \\
\text { della fatica del lavoro }\end{array}$ & 3.49 & .95 & -.35 & -.15 & .23 & .000 & .89 & .000 \\
\hline $\begin{array}{l}\text { 4b. Receiving a patient's } \\
\text { thanks is enough to } \\
\text { make you realise why } \\
\text { everyday you feel } \\
\text { committed to your job }\end{array}$ & $\begin{array}{l}\text { 4b. Per capire perché } \\
\text { ci si impegna ogni } \\
\text { giorno al lavoro basta } \\
\text { sentirsi dire grazie } \\
\text { da un paziente }\end{array}$ & 2.99 & 1.10 & .09 & -.78 & .18 & .000 & .91 & .000 \\
\hline $\begin{array}{l}\text { 5b. Patients' thanks } \\
\text { are the reward for } \\
\text { the work you do }\end{array}$ & $\begin{array}{l}\text { 5b. Il grazie dei pazienti } \\
\text { è la ricompensa per } \\
\text { il lavoro che si fa }\end{array}$ & 3.15 & 1.04 & -.08 & -.66 & .19 & .000 & .91 & .000 \\
\hline $\begin{array}{l}\text { 6b. Patients' thanks } \\
\text { give meaning to } \\
\text { everyday’s work }\end{array}$ & $\begin{array}{l}\text { 6b. Il grazie dei pazienti } \\
\text { restituisce senso al } \\
\text { lavoro di ogni giorno }\end{array}$ & 3.20 & 1.05 & -.14 & -.67 & .20 & .000 & .91 & .000 \\
\hline $\begin{array}{l}\text { 7b. A "thank you" } \\
\text { helps to understand } \\
\text { the meaning of the } \\
\text { actions carried out } \\
\text { every day at work }\end{array}$ & $\begin{array}{l}\text { 7b. Un grazie aiuta } \\
\text { a comprendere il } \\
\text { significato dei gesti } \\
\text { che si compiono ogni } \\
\text { giorno al lavoro }\end{array}$ & 3.37 & .94 & -.13 & -.31 & .21 & .000 & .90 & .000 \\
\hline
\end{tabular}


normality test of Kolmogorov-Smirnov and of Shapiro-Wilk suggest rejecting the hypothesis of normality of the distributions.

\subsection{Exploratory Factor Analysis and Reliability}

\subsubsection{Gratitude Perceived by Operators Scale}

As the items of the scale have no a normal distribution, we conducted exploratory factor analysis with the Generalized Least Squares extraction method. By the "Eigenvalues-greater-than-1" criterion, it resulted in a one factor solution (Table 3). The calculation of Cronbach's alpha suggested, then, to eliminate one item. We thus obtained a one-factor-solution (explained variance 69.81\%) composed of 4 items, which show quite high saturations. The index of reliability, Cronbach's alpha, for this sample is .90.

\subsubsection{Perception of Support Offered by Patients/Customers' Gratitude Scale}

Exploratory factor analysis (Generalized Least Squares extraction method) points out a one-factor solution also for this scale (Table 4). The factor shows high saturations corresponding to the 7 items of the scale. Explained variance is $73.09 \%$. Cronbach's alpha, for this sample, is .95.

\subsection{T-Test for Independent Samples}

\subsubsection{Gratitude Perceived by Operators Scale}

The T-test for independent samples highlights that people who have families to care for experience significantly more Gratitude perceived by operators ( $M$ 15.36, SD 3.32), compared to those who do not $(M 13.94, S D 3.43)$ $[t(266)=2.55, p<.05]$; the effect size measured with Cohen's $d$ was .42. No differences emerged, on the contrary, between women and men, or between people who have children and people who have not.

\subsubsection{Perception of Support Offered by Patients/Customers' Gratitude Scale}

The T-test for independent samples highlights that women have significantly higher Perception of support offered by patients/customers' gratitude ( $M$ 23.80, $S D$ 5.92) than men $(M$ 19.97, $S D$ 5.83) $[t(260)=3.66, p<.001]$; the effect size measured with Cohen's $d$ was .65 . People who have families to care show score significantly higher ( $M$ 27.30, SD 5.64) than people who do not $(M$ 22.67, $S D$ 6.48) $[t(264)=4.27, p<.001]$; the effect size

Table 3. Factorial solution for the gratitude perceived by operators scale.

\begin{tabular}{cc} 
Gratitude perceived by operators scale & Factor loadings \\
2a. Several patients appreciate our work & .931 \\
1a. Several patients express gratitude for the care we offer them & .854 \\
3a. Our patients often thank us for the care we offer them & .850 \\
5a. The patients can thank in many ways for the care they receive & .687 \\
\hline
\end{tabular}

Table 4. Factorial solution for the perception of support offered by patients/customers' gratitude scale.

Table 4. Factorial solution for the perception of support offered by patients/customers’ gratitude scale.
Perception of support offered by patients/customers' gratitude scale
6b. Patients' thanks give meaning to everyday's work
5b. Patients' thanks are the reward for the work you do
2b. A “Thank you” from a patient allows you to face your workload with much more enthusiasm
3b. Some patients' gratitude repays for the efforts at work
4b. Receiving a patient's thanks is enough to make you realise why everyday you feel committed to your job
7b. A “thank you” helps to understand the meaning of the actions carried out every day at work
1b. When one is thanked by your patients working seems less heavy


measured with Cohen's $d$ was .76. Also for this scale, no differences emerged, on the contrary, between people who have children and people who do not.

\subsection{Bivariate Correlation}

\subsubsection{Gratitude Perceived by Operators Scale}

As Table 5 shows, Gratitude perceived by operators highly correlates with both Perception of support offered by patients' gratitude and with Customers-initiated support. On the contrary, no correlations with Customer-related social stressors are shown, nor with age, job tenure in the sector or worked hours per week.

\subsubsection{Perception of Support Offered by Patients/Customers' Gratitude Scale}

Similarly, the scale of Perception of support offered by patients/customers' gratitude shows a high correlation both with Gratitude perceived by operators and with Customers-initiated support. Also in this case, no correlations are shown with Customer-related social stressors, nor with age, job tenure in the sector or worked hours per week.

\section{Discussion and Conclusion}

Aim of this work was the development and the analysis of two scales devoted to measure the gratitude expressed by patients and the perception of support that gratitude by patients/customers offers, in order to fill the gap of the absence, to our knowledge, of an instrument to measure the positive side of the relationship between patients and health operators: gratitude for received service and caring is an aspect that seems central in these workers' experience.

In line with expectations, the first analysis to validate the instruments suggested a one-factor solution for both scales, with good internal reliability. Moreover, as the analysis of variance points out, both of them can discriminate between groups of subjects. Proceeding to verify the validity of the instruments, bivariate correlations have given away a low and non-significant relationship with the construct of customer-related social stressors and a high significant correlation with the analogous construct of customers-initiated support (even if this scale has no Italian validated version yet): in this way, we obtained a first confirmation of both divergent and convergent validity. The two scales show good psychometric properties and a new administration of the instruments to a larger sample of helping professionals in several sectors (nurses, front-office workers and educators) is now being performed to overcome the limitations of the present work (the sample was composed of a small number of subjects from the same geographical area; we only conducted initial analyses of the validation process). The ongoing research work will consent to confirm the internal structure of the Gratitude perceived by operators and of Perception of support offered by patients' gratitude scales and to investigate more thoroughly their psycho-

Table 5. Bivariate correlations.

\begin{tabular}{|c|c|c|c|c|c|c|c|}
\hline & 1 & 2 & 3 & 4 & 5 & 6 & 7 \\
\hline 1. Gratitude perceived by operators & - & & & & & & \\
\hline 2. Perception of support offered by patients' gratitude & $.51^{* *}$ & - & & & & & \\
\hline 3. Customer-related social stressors & -.12 & .01 & - & & & & \\
\hline 4. Customers-initiated support & $.57^{* *}$ & $.44^{* *}$ & $-.28^{* *}$ & - & & & \\
\hline 5. Age & .10 & $.14^{*}$ & .04 & -.01 & - & & \\
\hline 6. Job tenure in the health sector & .05 & .10 & -.12 & .13 & $.68^{* *}$ & - & \\
\hline 7. Worked hours per week & .05 & .01 & -.17 & -.01 & -.11 & -.06 & - \\
\hline$M$ & 14.11 & 23.25 & 31.50 & 17.81 & 42.35 & 17.10 & 37.56 \\
\hline$S D$ & 3.05 & 6.01 & 14.60 & 3.32 & 8.10 & 9.04 & 4.81 \\
\hline Cronbach's Alpha & .89 & .95 & .92 & .83 & - & - & - \\
\hline
\end{tabular}

Note: ${ }^{*} p<.05,{ }^{* *} p<.001$. 
metric characteristics. Therefore, it will allow us to examine the relationships of the scales with several other constructs (as e.g. burnout) relative to care and service professions. Using the data collected, we will moreover suggest an Italian adaptation of the Zimmerman and colleagues' (2011) Customer-initiated support scale.

Helping professions are specifically characterized by the relationship with "others", a relationship that can be perceived either positively or negatively. It would, therefore, be interesting-for both theoretical research and research applied in organizations-to offer the possibility of measuring both these aspects by ad hoc instrumentsbrief and one-factor structured-able to be easily inserted in large instruments that analyze several dimensions, such as the Gratitude perceived by operators scale and the Perception of support offered by patients' gratitude scale, joint to the Social support scale (Converso et al., 2009), on one side, and of the Customer-related social stressors (Dormann \& Zapf, 2008) on the other. Assessing the absence or presence of the positive side of the relationship with patients, especially in contexts where such relationship lasts for a long time and is central to the process of caring, may have the significance-in organizational practice-of guiding managers to ponder resources and to develop organizational interventions and/or actions. In this way, workers' motivational processes and job satisfaction may be supported. Furthermore, devices-functional to face efforts and requests of a daily physically and emotionally demanding and involving job-may become available for helping professionals, such as nurses and health operators.

\section{References}

Balbo, L. (1982). Crazy Quilts, la riproduzione sociale ed il lavoro di servizio [Crazy Quilts, Social Reproduction and the Work of Service]. In G. Statera (Ed.), Consenso e conflitto nella società contemporanea [Consensus and Conflict in Contemporary Society] (pp. 47-51). Milano: Franco Angeli.

Bakker, A. B., Demerouti, E., \& Schaufeli, W. B. (2003). Dual Processes at Work in a Call Centre: An Application of the Job Demands a Resources Model. European Journal of Work and Organizational Psychology, 12, 393-417. http://dx.doi.org/10.1080/13594320344000165

Campbell, D. T., \& Fiske, D. W. (1959). Convergent and Discriminant Validation by the Multitrait-Multimethod Matrix. Psychological Bulletin, 56, 81-105. http://dx.doi.org/10.1037/h0046016

Colombo, L., Zito, M., \& Ghislieri, C. (2012). Influenza lavoro-famiglia e supporti sociali: La soddisfazione lavorativa in un'azienda sanitaria del Nord Italia. Differenze tra personale sanitario e amministrativo [Work-to-Family Influence and Social Supports: Job Satisfaction in a North-Italy Public Health Organization. Differences between Medical and Administrative Staff]. Giornale Italiano di Medicina del Lavoro ed Ergonomia. Supplemento di Psicologia Applicata alla Medicina del Lavoro e della Riabilitazione, 34, A25-A33.

Converso, D., Gattino, S., \& Loera, B. (2009). Antecedenti della sindrome di burnout nella Sanità pubblica: Fattori interpersonali e organizzativi [Organizational Justice, Social Support and Burnout amongst Health Care Workers: Direct and Moderating Effects of Social Support]. Risorsa Uomo, 15, 241-258.

Cox, T., Kuk, G., \& Leiter, M. P. (1993). Burnout, Health, Work Stress, and Organizational Healthiness. In W. B. Schaufeli, C. Maslach, \& T. Marek (Eds.), Professional Burnout: Recent Developments in Theory and Research. Series in Applied Psychology: Social Issues and Questions (pp. 177-193). Philadelphia: Taylor \& Francis.

Dormann, C., \& Zapf, D. (2004). Customer-Related Social Stressors and Burnout. Journal of Occupational Health Psychology, 9, 61-82. http://dx.doi.org/10.1037/1076-8998.9.1.61

Emmons, R. A. (2007). Thanks!: How the New Science of Gratitude Can Make You Happier. New York: Houghton Mifflin Company.

Ferrara, M., Converso, D., \& Viotti, S. (2013). Patient Satisfaction and Occupational Health of Workers in Hospital Care Setting: Associations and Reciprocity. Health, 5, 1622-1628. http://dx.doi.org/10.4236/health.2013.510218

Grandey, A. A., Fisk, G. M., \& Steiner, D. D. (2005). Must “Service with a Smile” Be Stressful? The Moderate Role of Personal Control for American and French Employees. Journal of Applied Psychology, 90, 893-904.

http://dx.doi.org/10.1037/0021-9010.90.5.893

Hasselhorn, H. M., Conway, P. M., Widerszal-Bazyl, M., Simon, M., Tackenberg, P., Schmidt, S., Camerino, D., Müller, B. H., \& NEXT Study Group (2008). Contribution of Job Strain to Nurses' Consideration of Leaving the Profession-Results from the Longitudinal European Nurses' Early Exit Study. Scandinavian Journal of Work, Environment \& Health Supplement, 6, 75-82.

Hinkin, T. R. (1998). A Brief Tutorial on the Development of Measures for Use in Survey Questionnaires. Organizational Research Methods, 1, 104-121. http://dx.doi.org/10.1177/109442819800100106

Homburg, C., \& Stock, R. (2004). The Link between Salespeople’s Job Satisfaction and Customer Satisfaction in a Business-to-Business Context: A Dyadic Analysis. Journal of the Academy of Marketing Science, 32, 144-158. 
http://dx.doi.org/10.1177/109442819800100106

Jourdain, G., \& Chênevert, D. (2010). Job Demands-Resources, Burnout and Intention to Leave the Nursing Profession: A Questionnaire Survey. International Journal of Nursing Studies, 47, 709-722. http://dx.doi.org/10.1016/j.ijnurstu.2009.11.007

Lazarus, R., \& Lazarus, B. (1994). Passion and Reason. Making Sense of Our Emotions. New York: Oxford University Press.

Lee, R. T., \& Ashforth, B. E. (1996). A Meta-Analytic Examination of the Correlates of the Three Dimensions of Job Burnout. Journal of Applied Psychology, 81, 123-133. http://dx.doi.org/10.1037/0021-9010.81.2.123

Lo Presti, A. (2013). Una valutazione del modello Job Demands-Resources su un campione di operatori della salute [An Evaluation of the Job Demands-Resources Model on a Sample of Health Care Workers]. Psicologia della Salute, 3, 51-74. http://dx.doi.org/10.3280/PDS2013-003003

Martini, M., \& Converso, D. (2012). Lo studio del burnout in sanità: Rapporto coi pazienti e relazione lavoro-famiglia come richieste e risorse. [Studying Burnout in the Healthcare: Relationship with the Patients and Work-Family Connection as Requests and Resources]. Giornale Italiano di Medicina del Lavoro ed Ergonomia. Supplemento di Psicologia Applicata alla Medicina del Lavoro e della Riabilitazione, 34, A41-A50.

Maslach, C. (1982). Burnout: The Cost of Caring. Englewood Cliffs, NJ: Prentice-Hall.

McCullough, M. E., Emmons, R. A., \& Tsang, J. (2002). The Grateful Disposition: A Conceptual and Empirical Topography. Journal of Personality and Social Psychology, 82, 112-127. http://dx.doi.org/10.1037/0022-3514.82.1.112

McCullough, M. E., Kilpatrick, S. D., Emmons, R. A., \& Larson, D. B. (2001). Is Gratitude a Moral Affect? Psychological Bulletin, 127, 249-266. http://dx.doi.org/10.1037/0033-2909.127.2.249

Mills, M. J., Fleck, C. R., \& Kozikowski, A. (2013). Positive Psychology at Work: A Conceptual Review, State-of-Practice Assessment, and a Look Ahead. The Journal of Positive Psychology, 8, 153-164. http://dx.doi.org/10.1080/17439760.2013.776622

Muthén, B., \& Kaplan, D. (1985). A Comparison of Some Methodologies for the Factor Analysis of Non-Normal Likert Variables. British Journal of Mathematical and Statistical Psychology, 38, 171-189. http://dx.doi.org/10.1111/j.2044-8317.1985.tb00832.x

Peterson, C., \& Seligman, M. E. P. (2004). Character Strengths and Virtues: A Handbook and Classification. New York: Oxford University Press and Washington DC: American Psychological Association. http://www.viacharacter.org

Rattray, J., \& Jones, M. C. (2005). Essential Elements of Questionnaire Design and Development. Journal of Clinical Nursing, 16, 234-243. http://dx.doi.org/10.1111/j.1365-2702.2006.01573.x

Razali, N. M., \& Wah, Y. B. (2011). Power Comparisons of Shapiro-Wilk, Kolmogorov-Smirnov, Lilliefors and AndersonDarling Tests. Journal of Statistical Modeling and Anlytics, 2, 21-33.

Selye, H. (1956). Stress of Life. New York: McGraw-Hill.

Taddei, S., \& Vanni, D. (2008). Customer-Related Social Stress and Burnout. A Contribution to the Italian Adaptation of the Customer-Related Social Stress Scale. Bollettino di Psicologia Applicata, 256, 41-53.

Toussaint, L., \& Friedman, P. (2008). Forgiveness, Gratitude, and Well-Being: The Mediating Role of Affect and Beliefs. Journal of Happiness Studies, 10, 635-654. http://dx.doi.org/10.1007/s10902-008-9111-8

Wright, B. E., \& Pandey, S. K. (2008). Public Service Motivation and the Assumption of Person-Organization Fit: Testing the Mediating Effect of Value Congruence. Administration \& Society, 40, 502-521. http://dx.doi.org/10.1177/0095399708320187

Zimmermann, B. K., Dormann, C., \& Dollard, M. F. (2011). On the Positive Aspects of Customers: Customer-Initiated Support and Affective Crossover in Employee-Customer Dyads. Journal of Occupational and Organizational Psychology, 84, 31-57. http://dx.doi.org/10.1111/j.2044-8325.2010.02011.x 